\title{
Traumatic injuries during the postoperative period after orthognathic surgery in patient with complete bilateral cleft lip and palate
}

\author{
Injúria traumática durante o período pós-operatório após cirurgia \\ ortognática em paciente com fissura transforame incisivo bilateral
}

\begin{abstract}
Purpose: Cleft lip and palate are the most common congenital deformities affecting the face and oral cavity. The procedure to be adopted when facing cleft lip and palate depends on their complexity, comprising treatment by an interdisciplinary team aiming at rehabilitation. Esthetic, functional and emotional implications occur in different manners and intensities, depending on the type of cleft. The aim of this paper is to guide professionals in this field, especially oral surgeons, for the treatment of patients with these congenital deformities and cases of postoperative complications.

Case description: The present case illustrates the treatment of a patient with complete bilateral cleft lip and palate, who suffered facial trauma in the postoperative period after orthognathic surgery. The clinical and radiographic success could be observed two years after the trauma by fall.

Conclusion: Patients submitted to orthognathic surgery are subject to postoperative complications. Infection, vehicle accidents, firearm accidents and domestic violence are among the most common causes of complications in the postoperative period. Knowledge on these problems allows the adoption of preventive measures to avoid serious complications mainly in patients with clefts who require an interdisciplinary team approach comprising multiple health care professionals.
\end{abstract}

Key words: Corrective orthodontics; cleft lip; malocclusion; Angle Class III; wounds and injuries

\section{Resumo}

Objetivo: As fissuras de lábio e palato representam as mais comuns das malformações congênitas que envolvem a face e a cavidade bucal. A conduta a ser tomada frente às fissuras de lábio e palato depende da severidade e complexidade das mesmas, através de um tratamento, por meio de uma equipe multidisciplinar, que vise à reabilitação. O propósito deste trabalho é fornecer orientação aos profissionais da área, especialmente, ao cirurgiãodentista, para realização do tratamento em pacientes com estes defeitos congênitos e em situações de complicações pós-operatórias.

Descrição do caso: $O$ caso clínico aqui relatado ilustra o tratamento de uma paciente portadora de fissura transforame incisivo bilateral completa de lábio e palato, que sofreu trauma facial no período de reabilitação, após a cirurgia ortognática. O sucesso clínico e radiográfico pôde ser observado dois anos após o trauma por queda.

Conclusão: Pacientes que realizaram cirurgia ortognática estão sujeitos a complicações pós-operatórias; infecção, acidentes com veículo motor, armas de fogo, violência doméstica estão entre as causas mais comuns citadas de complicações no pós-operatório tardio. $\bigcirc$ conhecimento dessas intercorrências possibilita que medidas preventivas sejam adotadas para evitarem-se complicações graves principalmente em pacientes com fissuras que necessitam da abordagem de uma equipe interdisciplinar composta por profissionais de saúde.

Palavras-chave: Ortodontia corretiva; fenda labial; maloclusão de Angle Classe III; ferimentos e lesões

\author{
Luciane Macedo de Menezes a \\ Susana Maria Deon Rizzatto a,b \\ Susiane Allgayer $a, b$ \\ Cláiton Heitz ${ }^{c}$ \\ a Department of Orthodontics, Pontifical Catholic \\ University of Rio Grande do Sul, Porto Alegre, RS, \\ Brazil \\ b Private practice, Porto Alegre, RS, Brazil \\ c Department of Oral and Maxillofacial Surgery, \\ Pontifical Catholic University of Rio Grande do Sul, \\ Porto Alegre, RS, Brazil
}

\author{
Correspondence: \\ Susiane Allgayer \\ Faculdade de Odontologia da PUCRS - Pontifícia \\ Universidade Católica do Rio Grande do Sul \\ Av. Ipiranga, 6681, Prédio 6, Sala 503 \\ Porto Alegre, RS - Brasil \\ 90619-900 \\ E-mail: susianeallgayer@ibest.com.br \\ E-mail: susianeallgayer@gmail.com \\ Received: September 11, 2011 \\ Accepted: November 23, 2011
}

Conflict of Interests: The authors state that there are no financial and personal conflicts of interest that could have inappropriately influenced their work.

Copyright: (c) 2011 Menezes et al.; licensee EDIPUCRS. This is an Open Access article distributed under the terms of the Creative Commons AttributionNoncommercial-No Derivative Works 3.0 Unported License. 


\section{Introduction}

Deficiency of the middle facial third is common in patients with clefts, often as a consequence of primary surgeries, causing anterior and/or posterior crossbite (1). In adult patients with marked jaw discrepancy, the orthodontic treatment should be combined to orthognathic surgery to enhance the esthetics, thus favoring the psychosocial aspects related to the deformity and achieving normal occlusion (2).

Cleft lip and palate cause anatomofunctional alterations that often ultimately lead to the indication of dental prostheses (3). The oral rehabilitation of patients with cleft lip and palate comprises a complex and very long treatment. Tooth crowding, rotations, malpositioning and partial eruption of teeth at the cleft area impair the oral hygiene and predispose to caries and periodontal disease, which ultimately leads to early tooth loss and frequently to the loss of several teeth. Several difficulties must be faced when performing dental prostheses for these patients. The deficiency of lip, bone and keratinized mucosa at the cleft area cause serious esthetic problems and impair the stability and retention (4).

Patients submitted to surgeries are subjected to complications in the late postoperative period (5), because of accidents or lack of compliance with postoperative care. A second surgical procedure may be necessary and the problem is further complicated when fixation plates are already present (6). Facial fractures, loose fixating screws or plate fractures are some complications that may occur. Knowledge on these aspects is important for the adoption of measured to reduce their occurrence.

The complete bilateral cleft lip and palate is among the most complex orofacial alterations and causes malocclusion, as well as dietary, swallowing, speech and breathing disorders, presenting different signs and symptoms whose solution may only be achieved by the collaborative work of a multidisciplinary team in the process of rehabilitation and social reinsertion of the patient. The present clinical case illustrates the correction of the aforementioned malocclusion and management of facial trauma occurring due to a fall after orthognathic surgery.

\section{Case description}

The female patient, aged 41 years, presenting complete bilateral cleft lip and palate, attended the Dental School at $\mathrm{xxx}$ after referral from her general practitioner for accomplishment of orthognathic surgery.

The initial facial photographs evidenced nasal asymmetry with deviation to the left side, mesofacial pattern, reduced nasolabial angle, increased lower third and slightly concave profile. During smiling she presented asymmetry and deficient smile. The intraoral photographs demonstrated that the patient already had an orthodontic appliance in both dental arches, presented Class I malocclusion, anterior open and cross bite. The maxillary midline was deviated in $3 \mathrm{~mm}$ and the mandibular midline in $2 \mathrm{~mm}$, both to the right side (Fig. 1 A-H).
The panoramic radiograph revealed absence of the maxillary right lateral incisor and third molar, maxillary left lateral incisor and third molar, mandibular left first and second molars, and mandibular right second premolar, second and third molars, horizontal resorption of alveolar crests and apical remodeling of the maxillary right central incisor, maxillary left central incisor, mandibular left central and lateral incisors, mandibular right central and lateral incisors. The occlusal radiograph of the maxilla evidenced the complete bilateral cleft lip and palate (Figs. 2A, 3A and 4A).

The main treatment objective was to correct the maxillomandibular discrepancy to obtain normal occlusion and consequently the function improvement of mastication, speech, breathing, swallowing and also the facial esthetics. The orthodontic therapy was combined to orthognathic surgery for maxillary advancement, bone graft at the cleft area and mentoplasty. After orthodontic-surgical treatment, the treatment plan included reshaping of the maxillary right and left central incisors and canines and replacement of the maxillary left lateral incisor and mandibular molars using implants and/or prostheses.

In the preoperative period, alignment and leveling was performed by changing the position of brackets on the maxillary left lateral incisor and mandibular left central incisor and first premolar, thereby eliminating the premature contacts, following by stainless steel archwires $0.016 ", 0.018 ", 0.020 ", 0.019$ " $\mathrm{x} 0.025$ " in the maxillary and mandibular arches.

Subsequent impressions were obtained to evaluate the intercuspation and simulate the surgical movements. The orthodontic records guided the surgical planning in collaboration with the maxillofacial surgeon (Figs. $4 \mathrm{~A}$ and $\mathrm{B} ; 5 \mathrm{~A}$ and $\mathrm{B})$. After cast surgery and predictive tracing, it was planned to perform maxillary advancement of $3 \mathrm{~mm}$ and chin advancement of $3 \mathrm{~mm}$. The patient received 0.020 " $\mathrm{X} 0.025$ " rectangular archwires with clipped hooks and postoperative recommendations (5).

The orthognathic surgery comprised a Le Fort I incision for maxillary advancement, mild rotation to the left side, segmentation on the left side, chin advancement and autogenous graft from the iliac crest at the cleft region, which were performed uneventfully (Figs. 3B, 4C and 5C).

At two months postoperatively, still during the recovery period, the patient suffered a fall from her own height with facial trauma. The panoramic radiograph requested for evaluation exhibited an image suggesting screw loosening (Fig. 2 B). The clinical signs presented - pain, edema and maxilla mobility (5) - required another surgical intervention, which confirmed the screw loss, with absence of bone or plate fracture. New plates were then fixated in the zygomatic bone (Fig. 2 C).

After surgery, the orthodontic treatment was continued by refinement of mechanics and attention to the finalization details. A wraparound retainer with a provision crown incorporated in the buccal arch at the region of the maxillary left lateral incisor was used until placement of the endosseous implant. The photographs present the patient two years after the trauma (Figs. 4 D; 5 D; 6 A-H). 

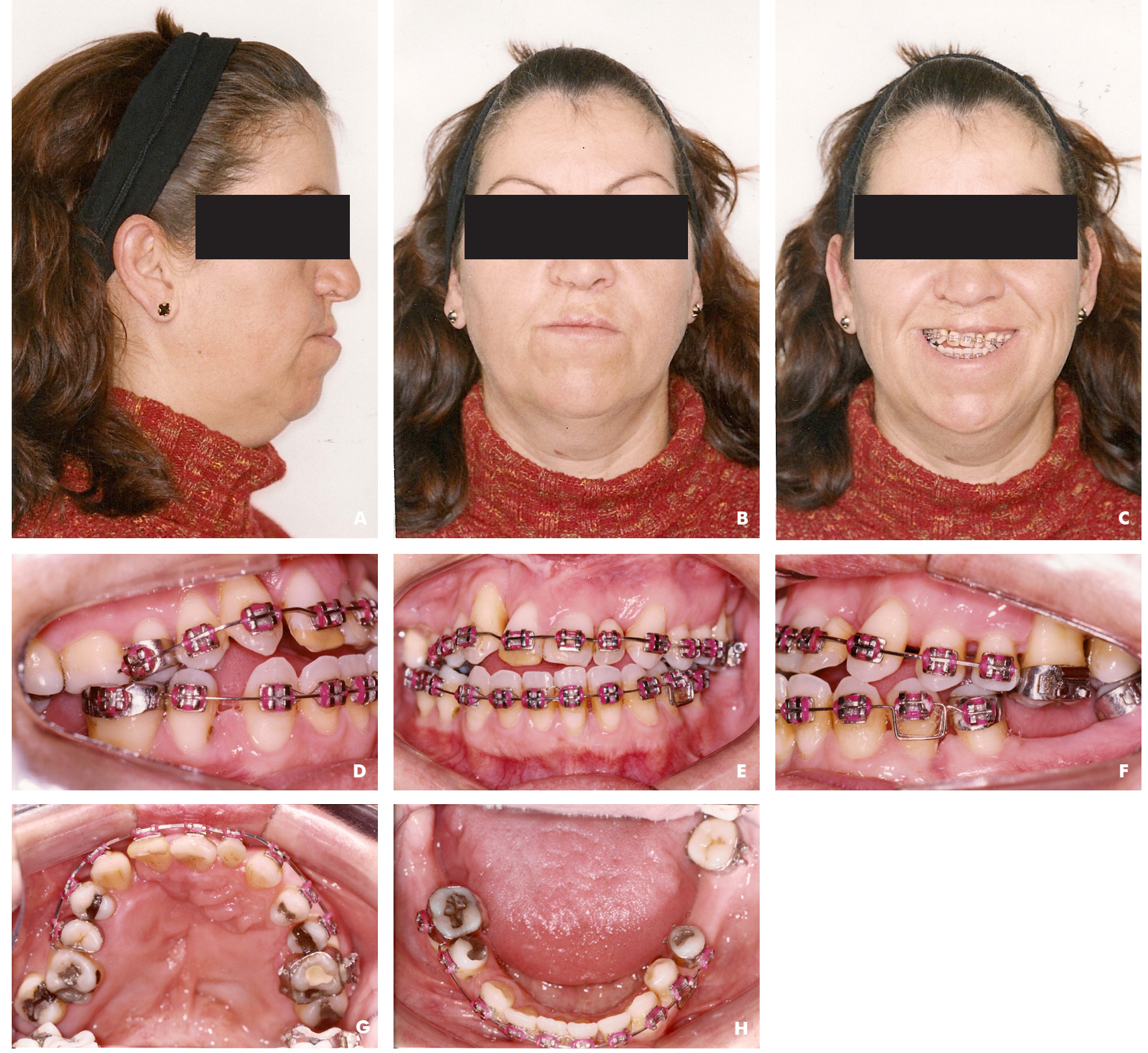

Fig. 1. (A-H) Initial facial and intraoral photographs.
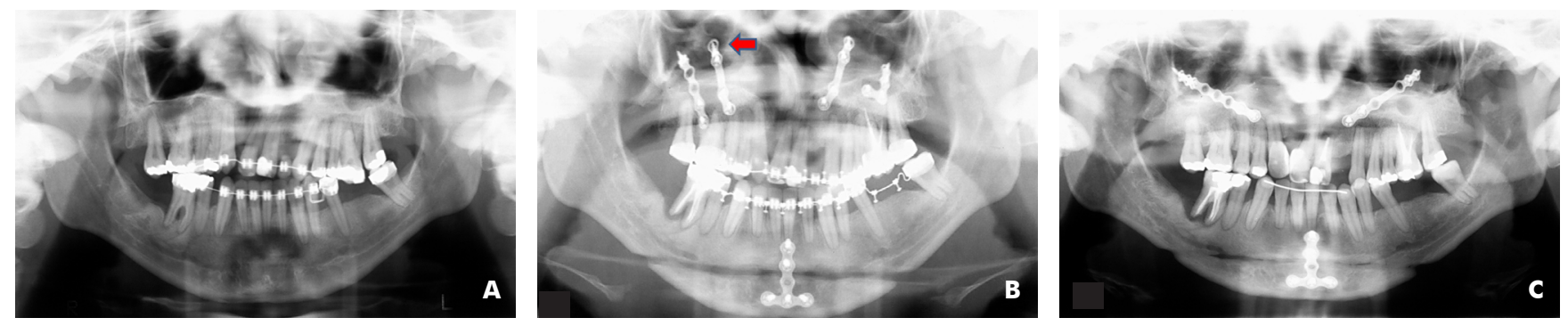

Fig. 2. Panoramic radiographs (A) initial; (B) after first surgery; (C) after second surgery and final. 

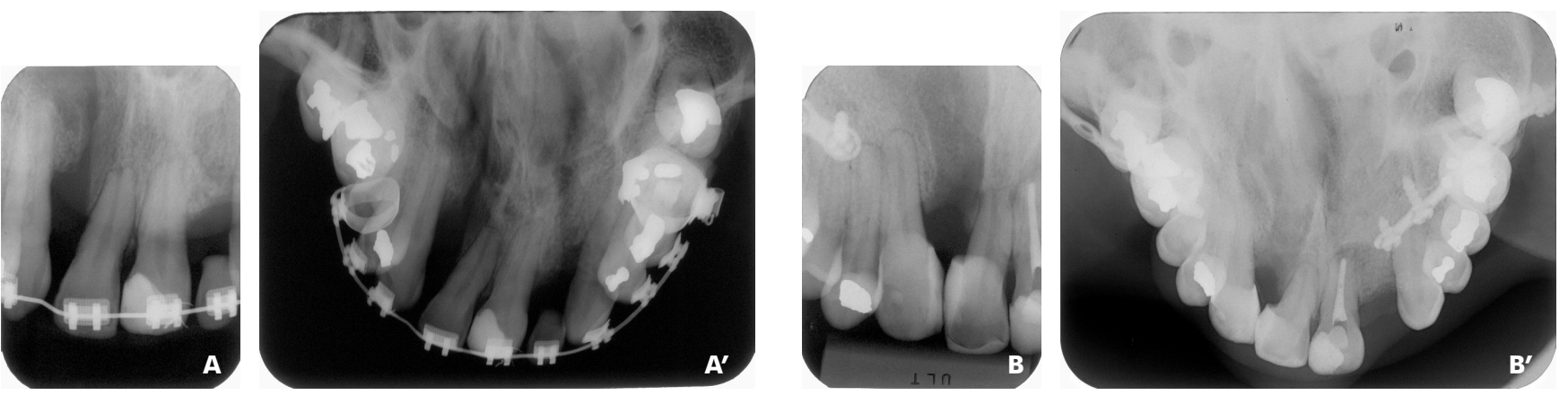

Fig. 3. Occlusal and periapical radiographs demonstrating: (A) alveolar cleft preoperatively, (B) alveolar segments of congenital lesion joined by the bone graft postoperatively.
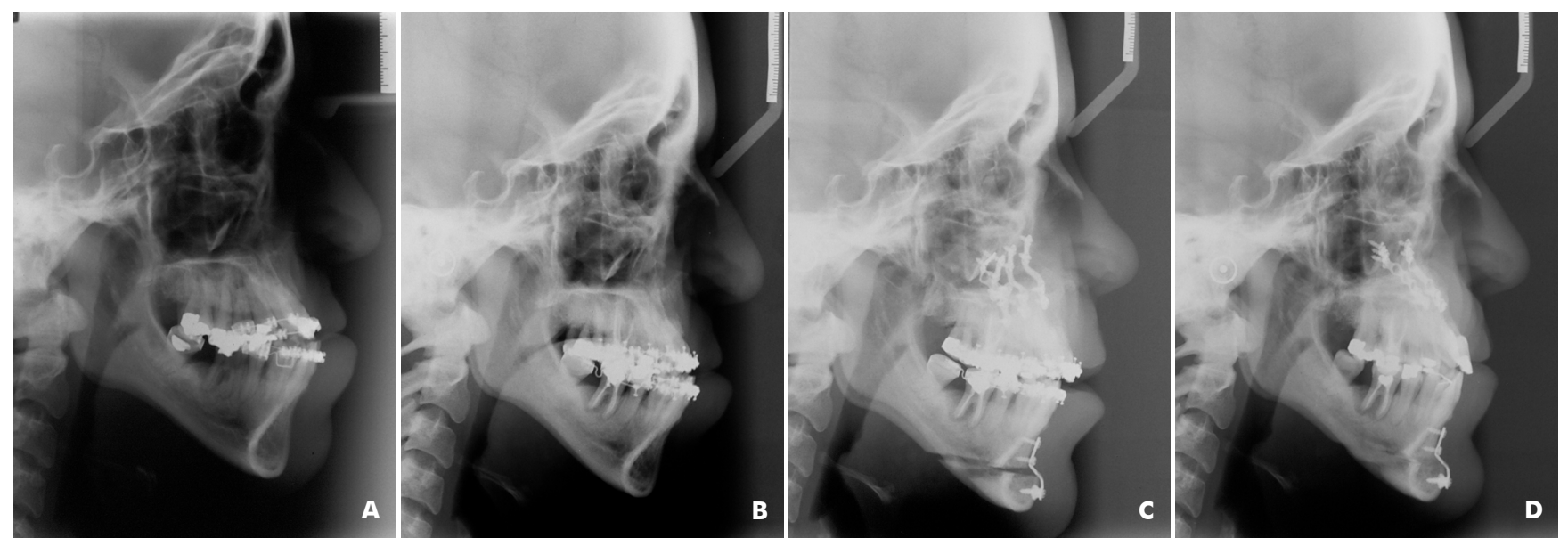

Fig. 4. Lateral cephalograms: (A) initial; (B) preoperative; (C) after first surgery and (D) after second surgery and final.
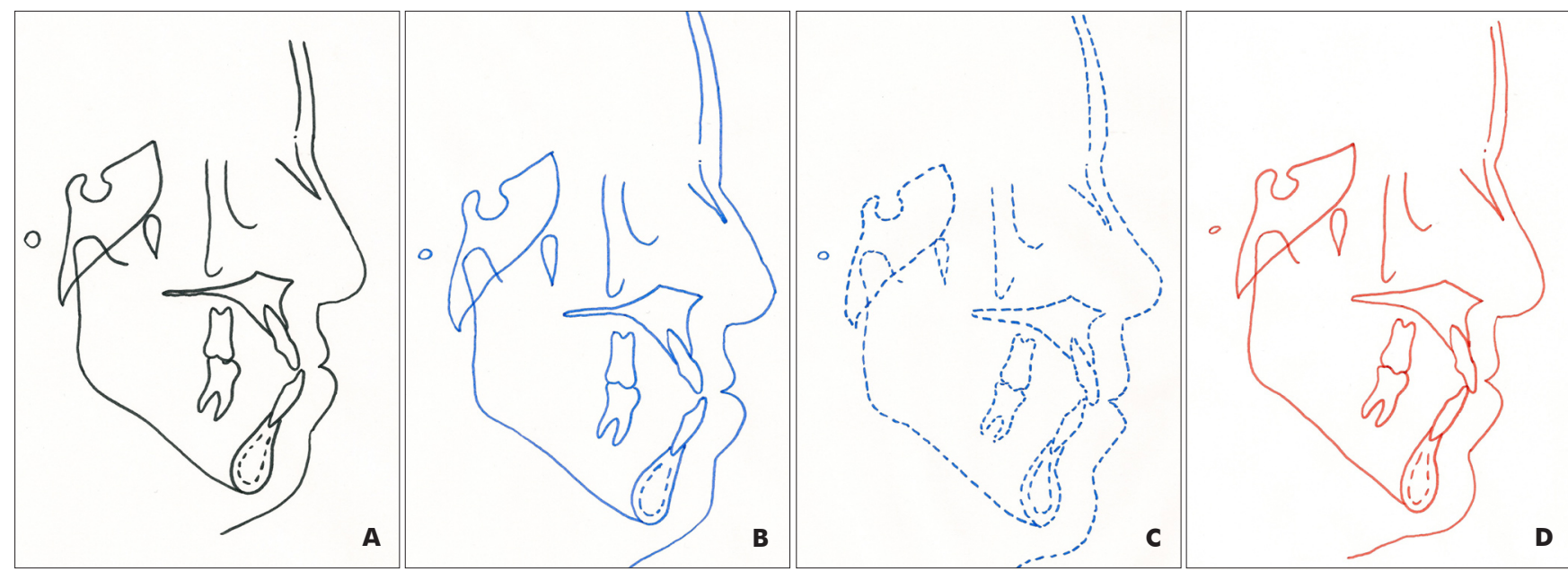

Fig. 5. Cephalometric tracings: (A) initial, (B) preoperative, (C) after first surgery, (D) after second surgery and final. 

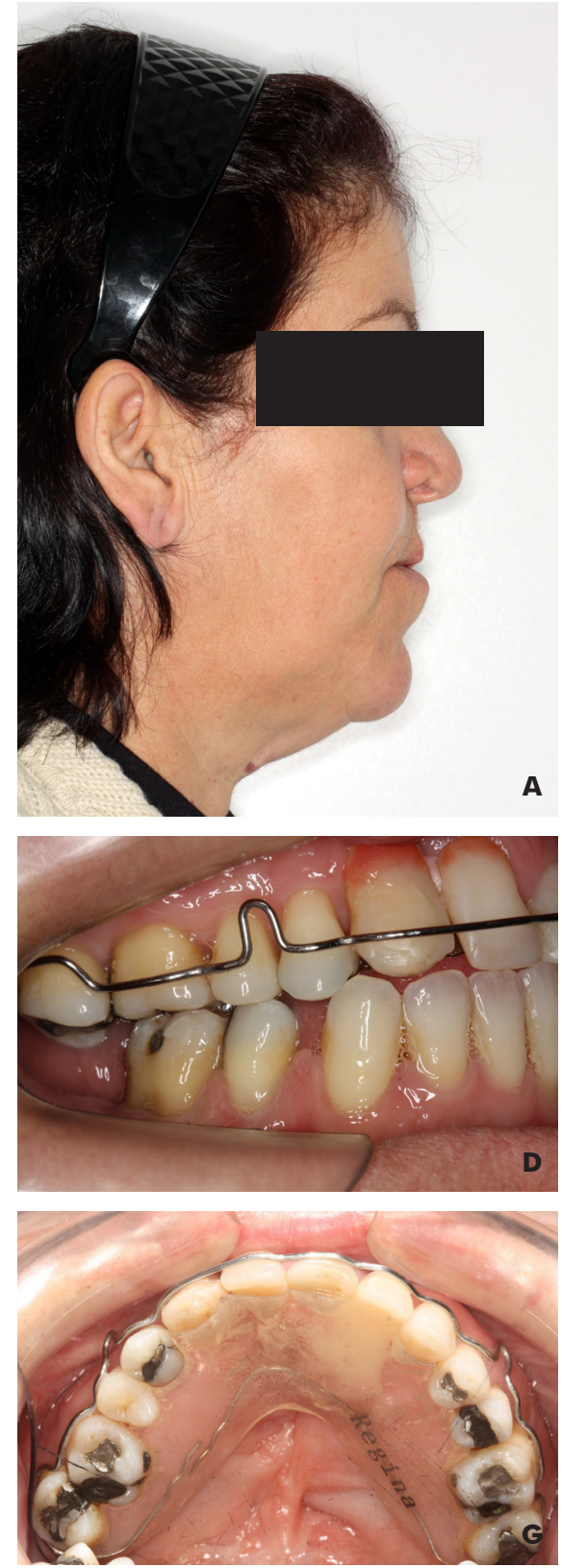

Fig. 6. (A-H) Final facial and intraoral photographs after two years of trauma by fall. The provisional crown on the maxillary left lateral incisor was incorporated in the buccal arch of the wraparound retainer until accomplishment of the implant.
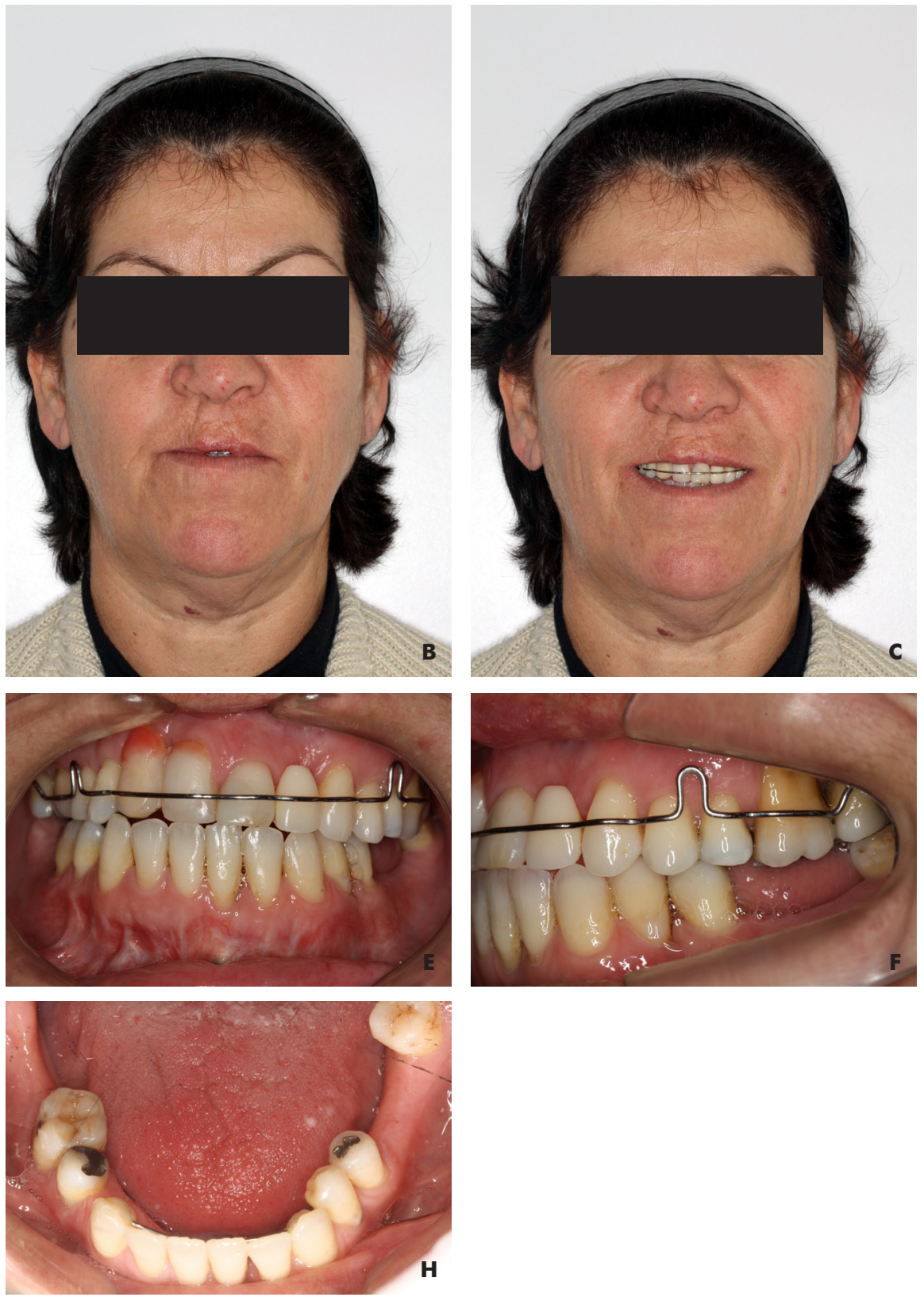

H

Fig. 7. Total cephalometric superimposition of initial and final cephalometric tracings with superimposition on the line SN and record on $\mathrm{N}$.

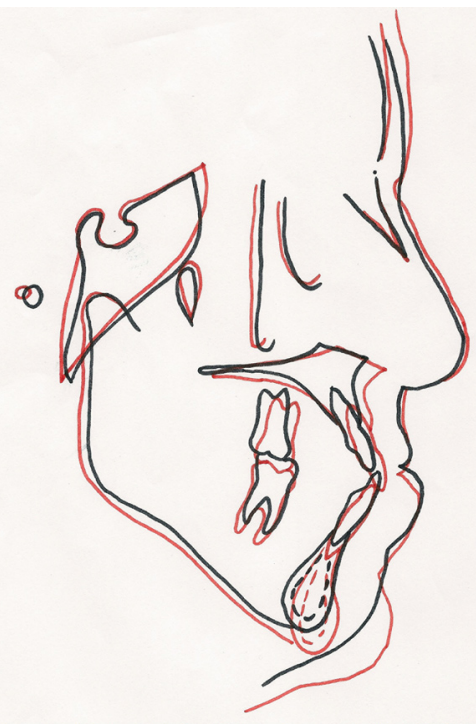




\section{Discussion}

The evaluation of occlusion, cephalometric findings, facial and dental cast analysis were determinant to confirm the orthodontic-surgical treatment. The dentofacial deformity presented by the patient could only be solved by the surgical procedure, yet the sagittal discrepancy between the dental arches was not severe enough to indicate a combined surgery in the maxilla and mandible. Whenever possible, the simplest surgical procedure should be performed, reducing the risks of trans- and postoperative complications for the patient, thereby facilitating the procedure for the maxillofacial surgeon and increasing the stability $(7,8)$.

The mandible exhibited increased length and open gonial angle, contributing to the vertical facial profile of the patient (9). Despite the increased maxillomandibular deficiency, the extremely open mandibular plane angle led to a retruded mandibular position in relation to the cranial base in the cephalometric analysis, thus leading to indication of surgery for mandibular setback and counterclockwise rotation (9), yet the facial analysis evidenced the severe anteroposterior deficiency of the middle facial third with depression on the infraorbital region, small width of the nasal base and poor projection of the upper lip, which highlighted the nose prominence (10) (Fig. $1 \mathrm{~A}-\mathrm{H})$.

The maxillary advancement increases the volume of the middle third and lip projection and also widens the nasal base, depending on the type of suture performed at the region of the anterior nasal spine (10). Furthermore, the surgery for maxillary advancement is considered stable $(2,9)$. Therefore, only maxillary advancement was planned to correct the occlusion, with chin advancement for additional esthetic improvement (8), this solving the two main problems, namely the concave profile and excessively vertical pattern of the patient.

The cephalometric analysis is particularly important to determine the surgical procedure required, yet it would be erroneous to assume that all patients should be treated according to these standards. The esthetic changes in chin repositioning described by some authors as a technical refinement involve mainly the lower lip, mentolabial groove, soft tissue pogonion and mentum-cervical distance. These structures usually follow the movement of the bone segments. The treatment effects may be well observed on the cephalometric superimpositions (Fig. 7).

The rupture of the alveolar process in patients with cleft lip and palate causes dental anomalies of number and shape, especially of the maxillary lateral incisors, whose tooth bud is directly affected by the lesion. With the advent of bone graft, which comprises filling the alveolar bone defect with autogenous or heterogeneous bone, it is possible to orthodontically move the teeth through the graft, displace adjacent teeth toward the missing tooth, or replace the missing tooth with an implant, as in the present case (11) (Fig $3 \mathrm{~A}-\mathrm{B}$ and $6 \mathrm{G}$ ).
The literature reports a high proportion of serious cases of postoperative complications with independent facial wounds (5), such as car or firearm accidents, domestic violence or infection (12), which are among the causes of postoperative complications. Patients submitted to surgical interventions may suffer injuries (5) and require re-operation, when the problem is more complicated and fixation plates are already present (6). Our finding is in accordance with previous reports that indicate $8 \%$ (13) to $41.3 \%$ (8) of postoperative complications because of screw loosening.

Combined to these facts, the surgical procedure causes stress (12), which interferes with the patient concentration capacity to understand the postoperative recommendations. It is advisable to provide the instructions both orally and in written form, the language should be easy to understand, without technical terms that may hardy be understood and impair the communication between professional and patient, especially among patients with low educational level (12). The literature highlights the importance of preoperative dialogue, to transmit reassurance and trust, reduce the anxiety, improve the understanding, increase the patient compliance with the care, improve the satisfaction and reduce the risks of morbidity (14); some authors further mention the psychological preparation (12).

As highlighted by Assael (15) "Our patients do not hear us. They often do not understand us. They sometimes do not recall what they may have initially understood. These lapses in communication can have negative consequences". Atchison et al. (12) evaluated the capacity of patients to recall the consent information and postoperative instructions. Only half of patients submitted to dental surgery remembered the informed consent, and less than half remembered the postoperative instructions. Audiovisual presentations of the postoperative care aid the understanding by the patients, thus reducing the anxiety and pain (14).

Once this fall occur during the first two months following surgery, that is, from immediately after surgery to shortly after completion of bone healing (5), the present approach with immediate identification of the problem and adequate intervention avoided more severe complications as bone necrosis and loss of the maxilla. The clinical and radiographic success could be observed two years after the trauma by fall (Figs. 4 D; 5 D;6 A-H). With this outcome, it may be concluded that the present approach was correct.

Ultimately, the combination of orthodontic therapy and orthognathic surgery allowed the achievement of satisfactory outcomes from esthetic, occlusal and functional standpoints in this case of complete bilateral cleft lip and palate, considering its complexity and the need of surgical reintervention. The importance of multidisciplinary treatment should be highlighted, which was fundamental to achieve this outcome. 
1. Vieira GL,Menezes LM,Lima EMS, Rizzatto SMD. Dentoskeletal Effects of Maxillary Protraction in Cleft Patients With Repetitive Weekly Protocol of Alternate Rapid Maxillary Expansions and Constrictions. Cleft Palate Craniofac J 2009;46:391-98.

2. Ueki K, Hashiba Y, Marukawa K, Yoshida K, Shimizu C, Nakagawa K, et al . Comparison ok maxillary stability after Le Fort I osteotomy for occlusal cant correction surgery and maxillary advanced surgery. Oral Surg Oral Méd Oral Pathol Oral Radiol Endod 2007; 104: 38-43.

3. Pinto JHN, Pegoraro-Krook MI. Evaluation of palatal prosthesis for the treatment of velopharyngeal dysfunction. J Appl Oral Sci 2003;1 1:192-7.

4. Stiévenart M., Malevez C. Rehabilitation of totally atrophied maxilla by means of four zygomatic implants and fixed prosthesis: a 6-40-month follow-up. Int J Oral Maxillofac Surg 2010;39:358-63

5. Epker BN, Stella JP, Fish LC. Dentofacial Deformities Integrated Orthodontic and Surgical Correction. 2a ed. St Louis, Missouri: Mosby; 1995.

6. Alpert B, Seligson D. Removal of asymptomatic bone plates used for orthognathic surgery and facial fractures. J Oral Maxillofac Surg 1996;54:618-21.

7. Ngan P. Early timely treatment of classe III malocclusion. Semin Orthod 2005;1 1:140-5.

8. Chow LK, Singh B, Chiu WK, Samman N. Prevalence of Postoperative Complications After Orthognathic Surgery: A 15-Year. Review. J Oral Maxillofac Surg 2007; 65:984-92.

9. Proffit WR, Phillips C, Turvey TA. Stability following superior repositioning of the maxilla by LeFort I osteotomy. Am J Orthod Dentofac Orthop 1987;92:151-61.

10. Del Santo LM, Souza RP, Del Santo JRM. Marcantonio E. Alterações no perfil dos lábios de pacientes submetidos a avanços maxilares em cirurgia ortognática do tipo Le Fort I. Rev Dent Press Ortodon Ortop Facial 2004;9:49-63

11. Silva Filho OG, Ferrari Junior FM, Capelozza Filho L, Albuquerque MVP. Enxerto ósseo alveolar em pacientes fissurados: realidade e perspectiva. Ortodontia 1995;28:34-45.

12. Atchison KA, Black EE, Leathers R, Belin TR, Abrego M, Gironda MW, et al. A qualitative report of patient problems and postoperative instructions. J Oral and Maxillofac Surg 2005;63:449-56.

13. Manor Y, Chaushu G, Taicher S. Risk factors contributing to symptomatic plate removal in orthognathic surgery patients. J Oral and Maxillofac Surg 1999;57:679-82.

14. Weis OF, Weintraub M, Sriwatanakul K, Lasagna L. Reduction of anxiety and postoperative analgesic requirements by audiovisual instruction. Lancet 1983;321:43-4.

15. Assael LA. Can you hear me now? Listening to our patients and ourselves. J Oral Maxillofac Surg 2005;63:425-6. 